\title{
A Questionnaire Based Survey Among the Patients Wearing Complete Dentures on Denture Staining
}

\author{
S. Shreya ${ }^{1}$, Dr. S. Sangeetha Kirubagaran ${ }^{2}$ \\ ${ }^{1}$ BDS II, Saveetha Dental College \\ ${ }^{2}$ Department of Prosthodontics, Saveetha Dental College
}

\begin{abstract}
Aim: A survey about the general knowledge among the denture wearers about denture staining. Objective: The main purpose of the study is to create an awareness among the people who wear dentures, about the various reasons that causes denture staining and give them a knowledge about the significance of maintaining a proper denture hygiene and to know about the methods that prevents staining of dentures. Background: Dentures are artificial prosthesis that replaces missing teeth. It's of great importance to keep the dentures clean because stained dentures can allow bacteria and other microbes to proliferate, leading to inflamed gums and halitosis. This study is done by creating a questionnaire regarding the various staining process of dentures among the users and analyzing the answers statistically. Reason: Dentures must be cleaned regularly in order to prevent staining from foods, drinks and smoking. The survey throws on light about the knowledge of people about the denture cleaning techniques and its significance.
\end{abstract}

Keywords: Denture staining, Cleansing habits, Frequency, Adverse habits, Denture maintenance, Aesthetics

\section{Introduction}

Oral hygiene seems to be an important perspective of dental study as it is concerned with the health state of a person. Several techniques are employed in our day to day life to ensure and maintain a good oral health. Dentures serves to be one of the most artificial substitutes which requires proper maintenance in order to be clean and prevent staining. Nearly half of the geriatric edentulous population relay upon complete denture to substitute their natural teeth. Complete denture aids in masticatory process, phonetics and also assures a confident smile to the patient. Apart from these, they should maintain the denture hygiene for its longevity and aesthetic maintenance. It is important to take care of the dentures in a much similar way we maintain our natural tooth, perhaps, a little extra care is required to avoid staining on dentures.

'Awareness is the first step of any change', awareness of the patient regarding denture staining \& its effect on the surrounding structures depends on either lack of knowledge or ignorance. So it is first important to evaluate the

\section{How Long have you been wearing a denture?}

\begin{tabular}{|l|r|r|}
\hline \multicolumn{1}{|c|}{ Response } & \multicolumn{1}{|c|}{$\begin{array}{c}\text { No.of } \\
\text { Respondants }\end{array}$} & Percentage \\
\hline $1-3$ Years & 18 & $36 \%$ \\
\hline $3-6$ Years & 19 & $38 \%$ \\
\hline More than 6 Years & 13 & $26 \% 6$ \\
\hline
\end{tabular}

percentage of awareness of complete denture patient regarding denture staining.

\section{Materials and Method}

- Research Design: Descriptive in nature

- Sampling technique: Stratified Random Sampling

- Data collective instrument: Questionnaire

- Sample Size: 50 complete denture patients were chosen among which 38 were male and 12 were female and a questionnaire containing 17 questions was surveyed. The survey included the opinion and views about denture cleansing routines and habits which leads to denture staining.

- Method: The survey concentrated on two divided age groups among which one population had patients below 60 years of age and the other group with patients above 60 years of age. The respective groups were surveyed.

- Data analysis and conclusion: The data obtained through questionnaire is synchronized and analyzed statistically.

\section{Data Analysis}

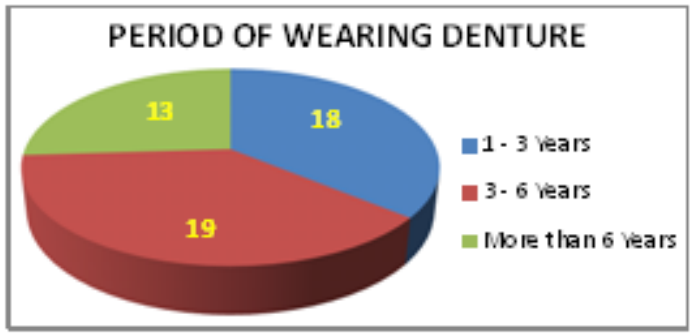




\section{International Journal of Science and Research (IJSR)}

ISSN (Online): 2319-7064

Index Copernicus Value (2013): 6.14 | Impact Factor (2015): 6.391

2. Do you drink coffee or tea regularly?

\begin{tabular}{|l|r|r|}
\hline \multicolumn{1}{|c|}{ Response } & \multicolumn{1}{|c|}{$\begin{array}{c}\text { No.of } \\
\text { Respondants }\end{array}$} & Percentage \\
\hline Yes & 40 & $80 \% 6$ \\
\hline No & 10 & $20 \% 6$ \\
\hline
\end{tabular}

3. If yes then at what intervals do you drin k?

\begin{tabular}{|l|r|r|}
\hline \multicolumn{1}{|c|}{ Response } & \multicolumn{1}{|c|}{$\begin{array}{c}\text { No.of } \\
\text { Respondants }\end{array}$} & Percentage \\
\hline 2 times a day & 28 & 7096 \\
\hline 3-5 times a day & 12 & $30 \% 6$ \\
\hline $\begin{array}{l}\text { More than 5 times a } \\
\text { day }\end{array}$ & 0 & 096 \\
\hline
\end{tabular}

FREQUENCY OF DRINKING COFFEE OR TEA

CONSUMPTION OF AERATED DRINKS

\begin{tabular}{|l|r|r|}
\hline \multicolumn{1}{|c|}{ Response } & \multicolumn{1}{|c|}{$\begin{array}{c}\text { No.of } \\
\text { Respondants }\end{array}$} & Percentage \\
\hline Yes & 15 & $30 \%$ \\
\hline No & 35 & $70 \%$ \\
\hline
\end{tabular}
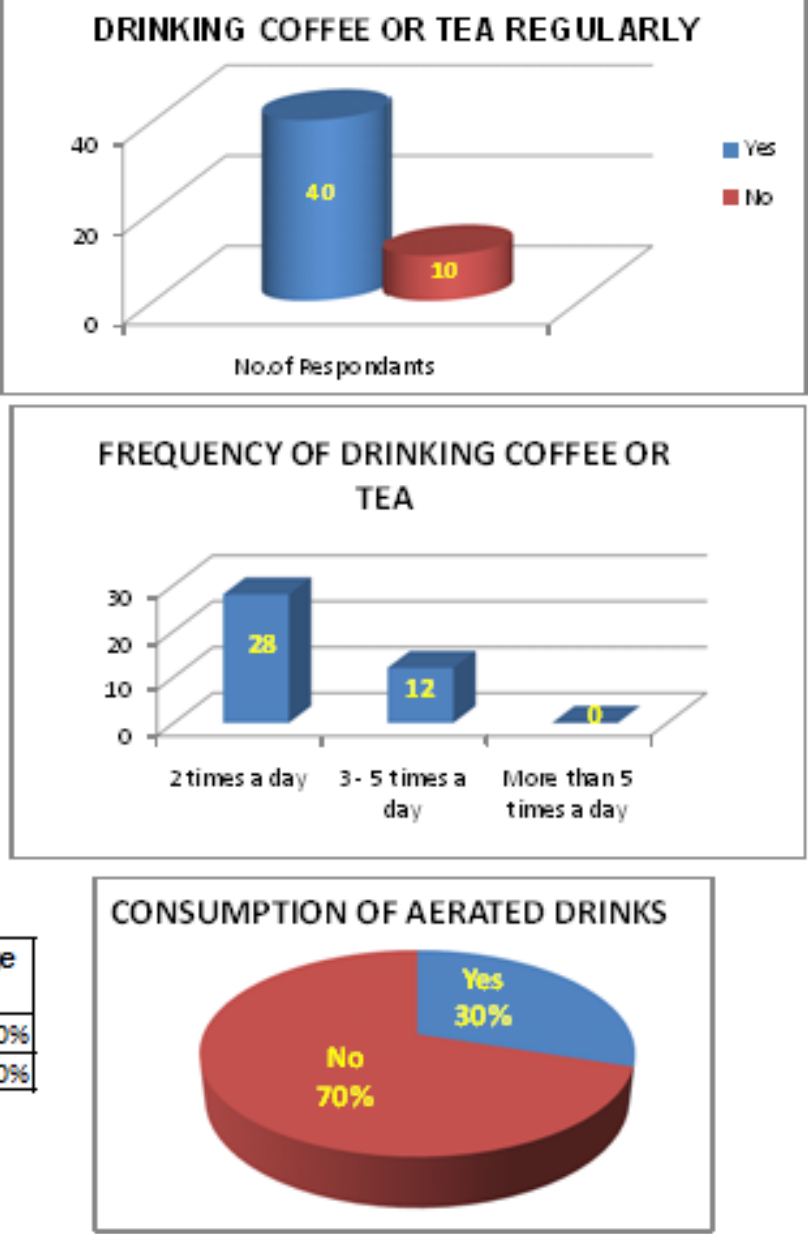

5. If yes, then what is the frequency of your consumption?

\begin{tabular}{|l|r|r|}
\hline \multicolumn{1}{|c|}{ Response } & \multicolumn{1}{c|}{$\begin{array}{c}\text { No.of } \\
\text { Respondants }\end{array}$} & Percentage \\
\hline Everyday & 1 & 796 \\
\hline $\begin{array}{l}\text { Frequently (more } \\
\text { than once a week) }\end{array}$ & 5 & $33 \%$ \\
\hline Occationally & 9 & $60 \% 6$ \\
\hline
\end{tabular}

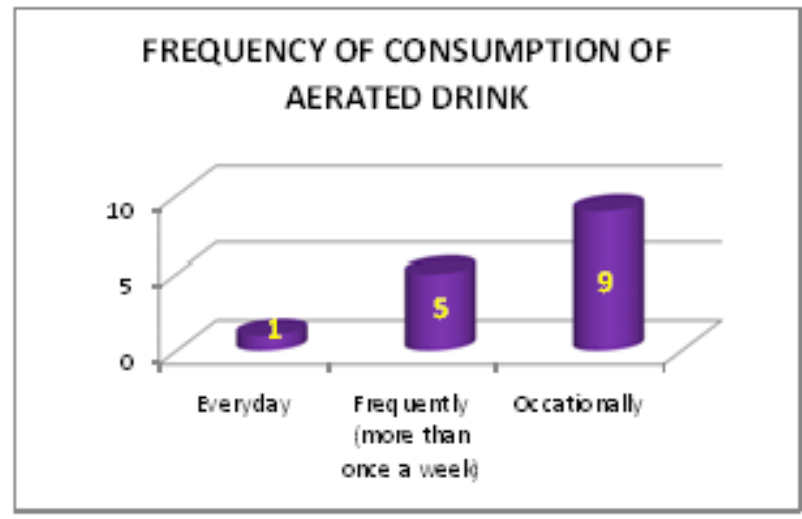

6. Do you have any of the following habits?

\begin{tabular}{|l|r|r|}
\hline \multicolumn{1}{|c|}{ Response } & \multicolumn{1}{|c|}{$\begin{array}{c}\text { No.of } \\
\text { Respondants }\end{array}$} & Percentage \\
\hline Drinking Alcohol & 2 & 496 \\
\hline Smoking & 5 & 1096 \\
\hline Pan chewing & 3 & 696 \\
\hline Tobacco chewing & 10 & 2096 \\
\hline None of the above & 30 & 6096 \\
\hline
\end{tabular}

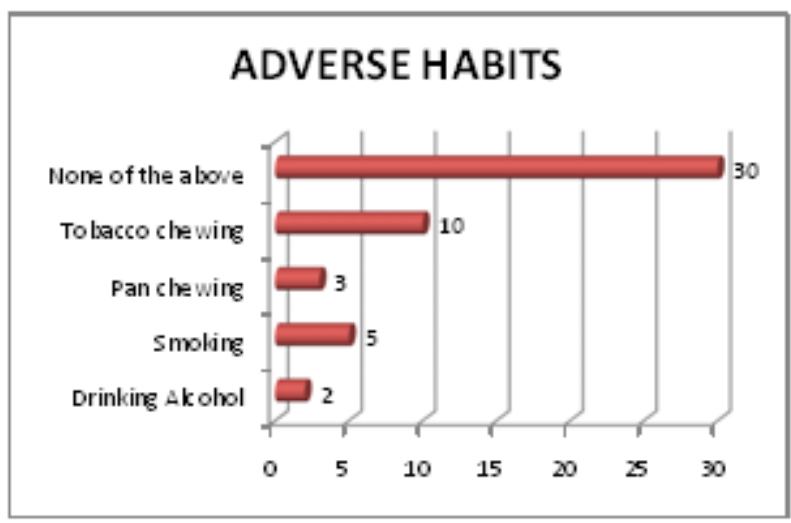

Volume 5 Issue 6, June 2016 www.ijsr.net

Licensed Under Creative Commons Attribution CC BY 


\section{International Journal of Science and Research (IJSR)}

ISSN (Online): 2319-7064

Index Copernicus Value (2013): 6.14 | Impact Factor (2015): 6.391

7. What is the frequency of those habits?

\begin{tabular}{|l|r|r|}
\hline \multicolumn{1}{|c|}{ Response } & \multicolumn{1}{|c|}{$\begin{array}{c}\text { No.of } \\
\text { Respondants }\end{array}$} & Percentage \\
\hline Very Frequently & 4 & $20 \% 6$ \\
\hline Frequently & 6 & $30 \% 6$ \\
\hline Occasionally & 10 & $50 \%$ \\
\hline
\end{tabular}

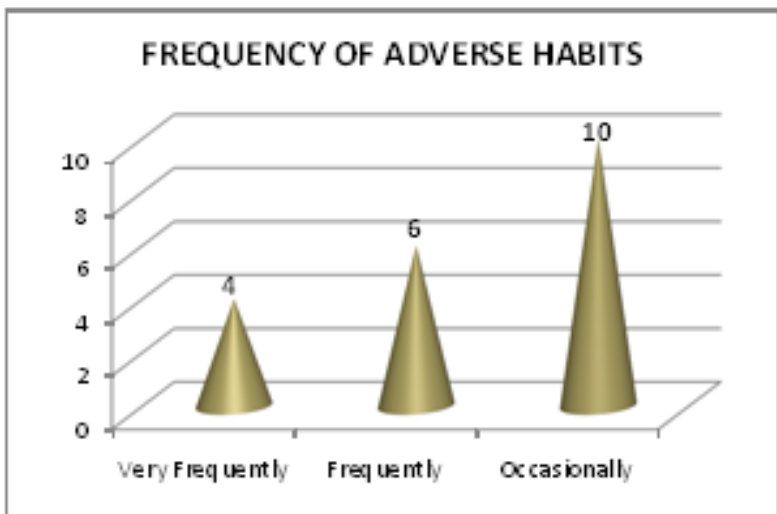

8. According to you which of the following causes denture staining?

\begin{tabular}{|l|r|r|}
\hline \multicolumn{1}{|c|}{ Response } & \multicolumn{1}{|c|}{$\begin{array}{c}\text { No.of } \\
\text { Respondants }\end{array}$} & Percentage \\
\hline Tea or Coffee & 46 & $21 \%$ \\
\hline Alcoholic drinks & 30 & $14 \%$ \\
\hline Aerated drinks & 48 & $22 \%$ \\
\hline Tobacco chewing & 45 & $20 \%$ \\
\hline Smoking & 27 & $12 \%$ \\
\hline $\begin{array}{l}\text { Improper diet and } \\
\text { brusing habits }\end{array}$ & 25 & $11 \%$ \\
\hline
\end{tabular}

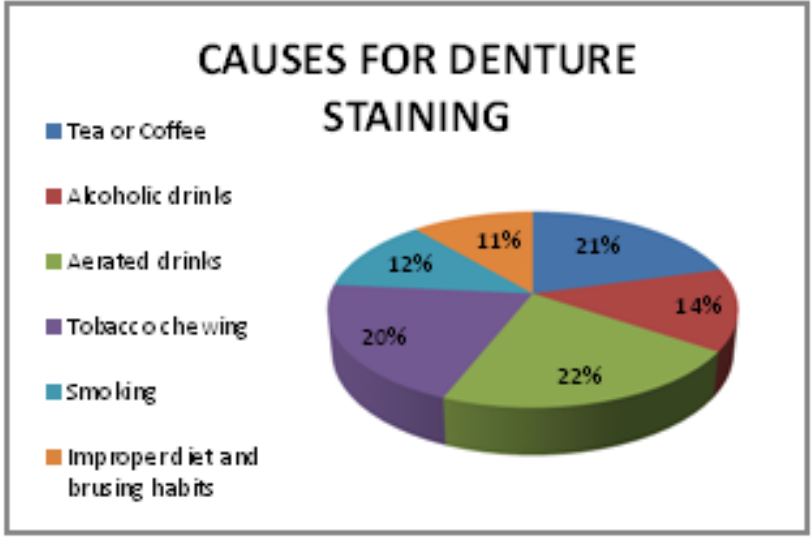

9. Did your dentist advice you on any denture cleaning techniques?

\begin{tabular}{|l|r|r|}
\hline \multicolumn{1}{|c|}{ Response } & \multicolumn{1}{|c|}{$\begin{array}{c}\text { No.of } \\
\text { Respondants }\end{array}$} & Percentage \\
\hline Yes & 38 & $76 \%$ \\
\hline No & 12 & $24 \%$ \\
\hline
\end{tabular}

\section{DENTIST ADVICE ON DENTURE CLEANING TECHNIQUES}

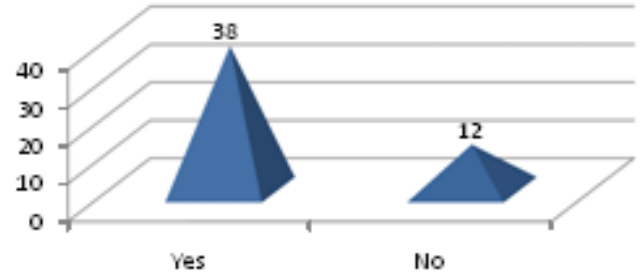

10. If yes, then what technique they recommend?

\begin{tabular}{|l|r|r|}
\hline \multicolumn{1}{|c|}{ Response } & \multicolumn{1}{c|}{$\begin{array}{c}\text { No.of } \\
\text { Respondants }\end{array}$} & Percentage \\
\hline $\begin{array}{l}\text { Soaking in salt } \\
\text { water over night }\end{array}$ & 9 & $60 \%$ \\
\hline $\begin{array}{l}\text { Using denture } \\
\text { cleaning solutions }\end{array}$ & & $13 \%$ \\
\hline $\begin{array}{l}\text { Professional } \\
\text { cleaning by a dental } \\
\text { technician }\end{array}$ & & \\
\hline
\end{tabular}

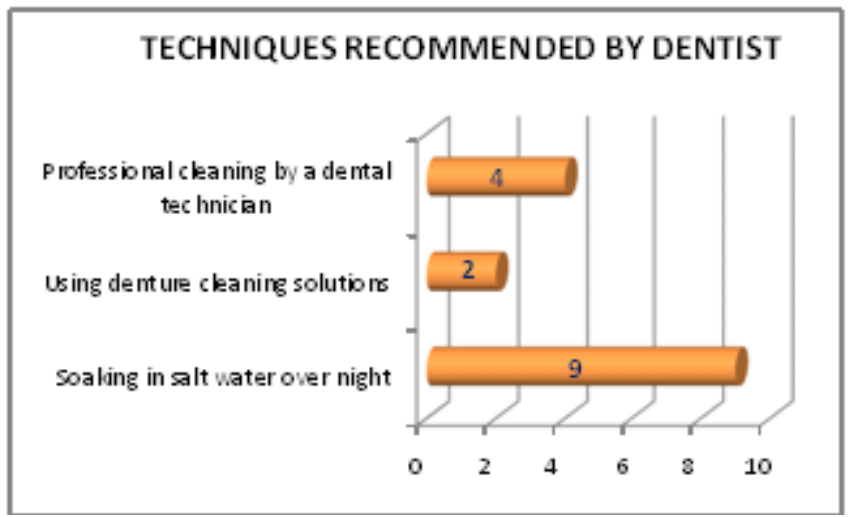

Volume 5 Issue 6, June 2016 www.ijsr.net

Licensed Under Creative Commons Attribution CC BY 


\section{International Journal of Science and Research (IJSR)}

ISSN (Online): 2319-7064

Index Copernicus Value (2013): 6.14 | Impact Factor (2015): 6.391

11. Do you clean your dentures?

\begin{tabular}{|l|r|r|}
\hline \multicolumn{1}{|c|}{ Response } & $\begin{array}{c}\text { No.of } \\
\text { Respondants }\end{array}$ & Percentage \\
\hline Yes & 50 & $100 \%$ \\
\hline No & 0 & $0 \%$ \\
\hline
\end{tabular}

\section{CLEANING OF DENTURES}

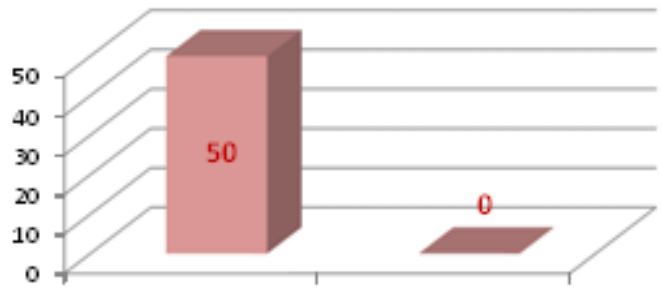

Yes

12. If yes then what method do you use to clean your dentures?

\begin{tabular}{|l|r|r|}
\hline \multicolumn{1}{|c|}{ Response } & \multicolumn{1}{|c|}{$\begin{array}{c}\text { No.of } \\
\text { Respondants }\end{array}$} & Percentage \\
\hline $\begin{array}{l}\text { By denture cleaning } \\
\text { solutions }\end{array}$ & 0 & $0 \%$ \\
\hline Rinsing with water & 38 & $76 \%$ \\
\hline Using tooth paste & 12 & $24 \%$ \\
\hline Using detergent & 0 & $0 \%$ \\
\hline
\end{tabular}

\section{METHODS USED TO CLEAN THE DENTURE}

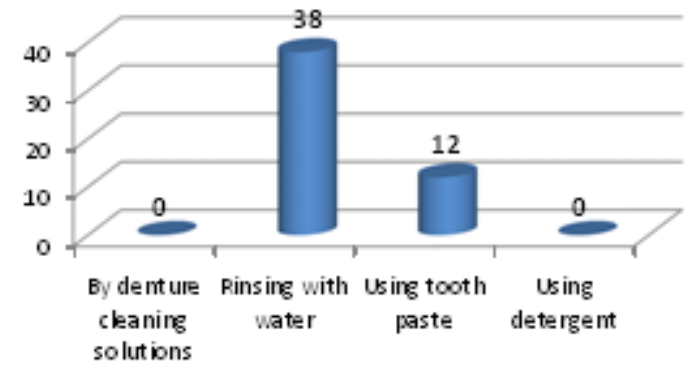

INTERVALS OF CLEANING THE DENTURE

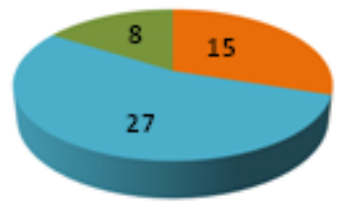

mwike a day mone a day mone int wodays

14. Do you suffer any of the following problems because of wearing a denture?

\begin{tabular}{|l|r|r|}
\hline \multicolumn{1}{|c|}{ Response } & \multicolumn{1}{|c|}{$\begin{array}{c}\text { No.of } \\
\text { Respondants }\end{array}$} & Percentage \\
\hline $\begin{array}{l}\text { Oral infection and } \\
\text { allergies }\end{array}$ & 6 & $12 \%$ \\
\hline $\begin{array}{l}\text { Ulcers of oral } \\
\text { mucosa }\end{array}$ & 25 & $50 \%$ \\
\hline Halitosis & 19 & $38 \%$ \\
\hline
\end{tabular}

15. Are you aware that stained dentures serves to be one of the reason for the above disconforts.

\begin{tabular}{|l|r|r|}
\hline \multicolumn{1}{|c|}{ Response } & \multicolumn{1}{|c|}{$\begin{array}{c}\text { No.of } \\
\text { Respondants }\end{array}$} & Percentage \\
\hline Yes & 28 & $56 \%$ \\
\hline No & 22 & $44 \%$ \\
\hline
\end{tabular}

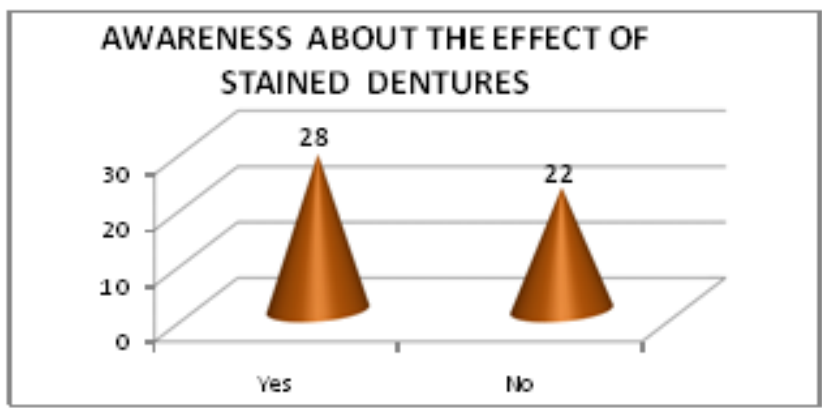

Volume 5 Issue 6, June 2016 www.ijsr.net

Licensed Under Creative Commons Attribution CC BY 


\section{International Journal of Science and Research (IJSR) \\ ISSN (Online): 2319-7064}

Index Copernicus Value (2013): 6.14 | Impact Factor (2015): 6.391

16. Are you comfortable of wearing a denture if it is stained?

\begin{tabular}{|l|r|r|}
\hline \multicolumn{1}{|c|}{ Response } & \multicolumn{1}{c|}{$\begin{array}{c}\text { No.of } \\
\text { Respondants }\end{array}$} & Percentage \\
\hline Yes & 0 & $0 \%$ \\
\hline No & 50 & $100 \%$ \\
\hline
\end{tabular}

\section{COMFORTNESS IN WEARING A STAINED DENTURE}

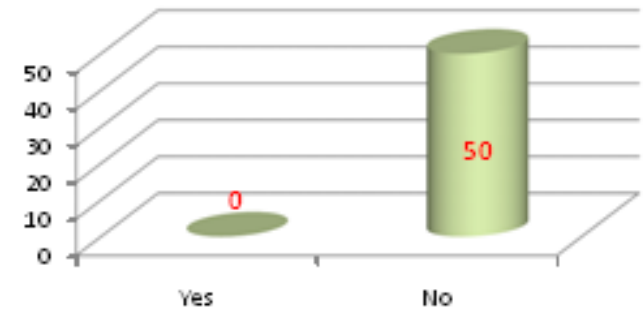

17. How will you evaluate your own denture maintenance?

\begin{tabular}{|l|r|r|}
\hline \multicolumn{1}{|c|}{ Response } & \multicolumn{1}{c|}{$\begin{array}{c}\text { No.of } \\
\text { Respondants }\end{array}$} & Percentage \\
\hline Good & 27 & $54 \%$ \\
\hline Fair & 14 & $28 \%$ \\
\hline Average & 9 & $18 \%$ \\
\hline Unsatisfactory & 0 & $0 \% 6$ \\
\hline
\end{tabular}

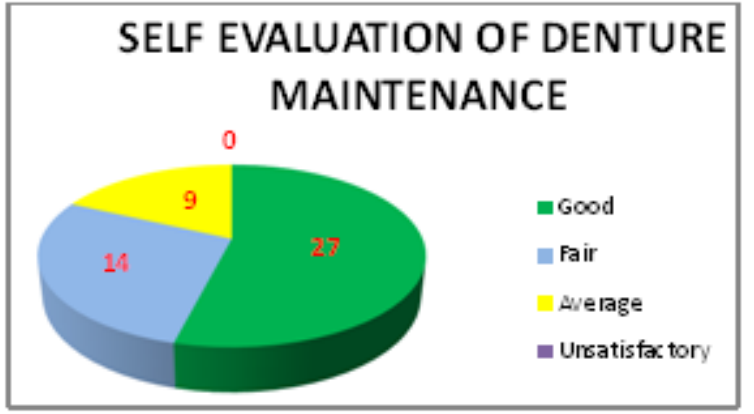

\section{Results}

The study on the awareness about denture staining on complete denture patients was surveyed among $26 \%$ of patients using dentures for more than 6 months, $36 \%$ of patients using it for 1-3 years and 38\% of patients using dentures for nearly 3-6 years. Among $80 \%$ of the patients claimed that they drink coffee or tea regularly out of which 28 patients drank for nearly 2 times and the rest for 3-5 times. Much of them said they do not drink aerated drinks due to various health issues like diabetes, blood pressure etc., as the survey focused on much of the geriatric patients but a few claimed that they drink aerated drinks occasionally.

With regard to adverse habits, $60 \%$ had no addiction to any adverse habits but $4 \%$ claimed that they drink alcoholic drinks, $10 \%$ had smoking habits, $6 \%$ had pan chewing habits and $10 \%$ were addicted to tobacco chewing. When the frequency of such adverse habits were asked, nearly $20 \%$ use them very frequently, $30 \%$ had frequent habits and $50 \%$ uses occasionally. $76 \%$ of the patients claimed that denture cleansing techniques was instructed by their dentist. $76 \%$ of patients rinsed the dentures with water and $12 \%$ used tooth paste and tooth brush. $12 \%$ of patients reported that they suffered from oral infections, candidiasis and allergies while the rest $38 \%$ suffered halitosis. Nearly $56 \%$ of the patients are aware that these problems are due to their stained dentures. When the patients were asked to evaluate their own denture maintenance only $54 \%$ of patients had a good denture maintenance.

\section{Discussion}

To create awareness, first knowledge among the patients about staining agents is necessary. Many answered that substances such as tea, coffee, aerated drinks, tobacco and habits like smoking, drinking causes denture staining. They also accepted that staining is due to improper diet, brushing techniques and cleaning routine. It was understood from the survey that almost. When asked about the advice of dentist, many answered that instructed techniques mainly included soaking in salt water overnight, cleaning using denture cleaning solutions and tablets, professional cleaning which mainly includes cleaning by dental technicians. Surprisingly almost all of the responders clean their dentures and the methods mainly employed in their day to day denture cleaning practice is by using a commercially available tooth paste and a tooth brush (24\%) where similar results were obtained in previous studies conducted by Peracini et al (1)and Jeganthan et al(2) that denture is cleaned by rinsing with water and by soaking overnights as advised by the dentist $(76 \%)$. Combination of brushing and soaking methods is recommended by dentists and it is similar to the studies conducted by Hoad Reddick et al (3) and Veres et al (4). A very few used diluted chlorhexidine mouth washes and a conventional method of using lemon and salt were also employed in denture cleaning. Regarding the frequency of cleaning habits, $54 \%$ of the patients cleaned the dentures 1 time a day where this result can be compared to that of Nevalainen et al(5) De Castelucci Barbosa et al(6) who obtained similar results, $30 \%$ cleaned the dentures twice a day and $16 \%$ cleaned one tine for every two days. This shows many were prone to denture staining and a few were also wearing a stained denture due to lack of awareness. Most of the Patients suffering from problems like oral candidiasis, infections and allergies, ulcers of the oral mucosa and halitosis due to wearing a stained denture. Only $50 \%$ of the patients reported a satisfactory denture usage because of using it only for 1-3 years with routine cleaning habits and the rest had either an average or an unsatisfactory experience due to long term usage without regular cleaning routines. The unsatisfactory experience is also due to lack of

\section{Volume 5 Issue 6, June 2016} www.ijsr.net 


\section{International Journal of Science and Research (IJSR) \\ ISSN (Online): 2319-7064}

Index Copernicus Value (2013): 6.14 | Impact Factor (2015): 6.391

knowledge and ignorance. Almost all claimed that they are not comfortable of wearing the denture if it was stained. Similar results were obtained in a survey by Abelson et al(7)

\section{Conclusion}

From the survey, the following results were drawn which includes,

1) Awareness about denture staining remains a questionable factor as many patients lacked knowledge about proper denture cleaning routines and cleansing habits.

2) Many were aware that consumption of Tea, coffee, aerated drinks and possessing sing other habits like drinking, smoking serves to cause denture staining.

3) Many used common tooth brush and tooth paste to clean the dentures. This shows that they are not updated with the chemical methods of denture cleansing to remove stains.

4) Most of the patients reported that they are not satisfied with their cleansing methods.

\section{References}

[1] Peracini et al Behaviors and Hygiene Habits of Complete Denture Wearers. Braz.Dent.J vol 21, 2010.

[2] Jeganathan, Denture stomatitis in an elderly edentulluos Asian population. J Oral Rehabil, 1997.

[3] Hoad-Reddick, Investigations into the cleanliness of dentures in an elderly population. J Prosthet Dent, 1990.

[4] Veres EM, A survey of materials and methodsemployed by denture wearers. J Dent Assoc SAfr, 1985.

[5] Nevalainen MJ, Oral Mucosa lesions and oral hygiene habits in the home living elderly, J Oral Rehabil, 1997.

[6] De Castelucci Barbosa L, Edentulous patient's knowledge of dental hygiene and care of prosthesis, Gerodontology 2008.

[7] Abelson D.C. Denture plaque and denturecleansers, Gerodontics 1985. 